\title{
Effects of body weight, height, and body mass index on thyroid volume among healthy undergraduate Saudi males using ultrasound.
}

\author{
Fahad A. Alsaqer ${ }^{*}$, Walid Al-Kulaib², M. Alkhorayef ${ }^{1}$, Mustafa Z. Mahmoud ${ }^{3}$, Abdelmoneim \\ Sulieman $^{3}$ \\ ${ }^{1}$ Department of Radiological Sciences, College of Applied Medical Sciences, King Saud University, Riyadh, Saudi \\ Arabia \\ ${ }^{2}$ Radiology Department, King Saud University Medical City, Riyadh, Saudi Arabia \\ ${ }^{3}$ Radiology and Medical Imaging Department, College of Applied Medical Sciences, Prince Sattam bin Abdulaziz \\ University, Al-Kharj, Saudi Arabia
}

\begin{abstract}
The aim of the current study was to correlate the effects of body weight, height, and body mass index (BMI) on thyroid volume of healthy undergraduate Saudi males by using ultrasound. After retaining an acceptance from the local ethics committee, a total of 100 (mean age was $21.8 \pm 1.3 \mathrm{y}$; ages range from 18 to 22 y) participants were recruited between September 2016 and January 2018 in this prospective cohort study. Ultrasonographic measurements of the gland were performed using a HI vision Avius ultrasound unit (Hitachi), equipped with a high frequency direct contact $10 \mathrm{MHz}$ linear array ultrasound probe. The calculated mean of thyroid volume was $7.5 \pm 2.4 \mathrm{ml}$ (right lobe volume was $3.9 \pm$ $1.6 \mathrm{ml}$ while that for left lobe was $3.6 \pm 1.2 \mathrm{ml})$. Extremely statistically significant correlation $(\mathbf{P}<0.0001)$ was found between gland volume $(\mathrm{ml})$ and participants' weight $(\mathrm{kg})$, height $(\mathrm{cm})$, and BMI $\left(\mathrm{kg} / \mathrm{m}^{2}\right)$. In conclusion, the estimated thyroid volume was decreased significantly as participants' weight and BMI increase. In contrast, the volume increases significantly as height increases. Also, a local reference of thyroid volume among healthy undergraduate Saudi males was conducted.
\end{abstract}

Keywords: Body height, Body mass index, Body weight, Goiter, Thyroid gland.

Accepted on March 6, 2018

\section{Introduction}

The thyroid gland is an essential endocrine gland in humans and other animals; it is situated in the infra-hyoid portion of the neck [1]. The gland contains many follicular cells that store the thyroid hormones within the thyroglobulin molecule until they are needed by the body. The thyroid hormones often referred to as the major metabolic hormones; affect virtually every cell in the body. Synthesis and secretion of the thyroid hormones depend on the presence of iodine and tyrosine as well as maturation of the hypothalamic-pituitary-thyroid system [2]. Iodine is crucially necessary for ordinary gland activity. Iodine attains the gland follicular cells as mineral iodide and is converted through sequences of metabolic actions into Tetraiodothyronine (T4) and Triiodothyronine (T3) hormones. Major steps of the iodine metabolism contain: 1) quick iodide transportation; 2) iodination of tyrosyl residues of Thyroglobulin (Tg); 3) connecting of iodotyrosine molecules to produce $\mathrm{T} 3$ and $\mathrm{T} 4$; 4) proteolysis of $\mathrm{Tg}$, with the liberate of unrestrained iodotyrosines with iodthyronines; 5) deiodination of iodotyrosines and reuse of extricated iodide and 6) deiodination of T4 to T3 [3].
The true measurement of thyroid size is essential in the investigation of the gland and rating its abnormalities. The size of the gland can be decided by palpation, Nuclear Medicine (NM) or Ultrasound (US). Nowadays US and NM are used in examining the adult thyroid gland [4-7]. The reliability of palpation particularly in children is inaccurate. Therefore, US is the most beneficial modality in determining the gland size in children [8]. In addition, US can be applied satisfactorily in testing cystic or solid masses of the gland and in determining extrathyroid or intrathyroidal pathologies $[6,9,10]$.

The valuation of the gland volume sonographically, is supported on the applied of an ellipsoid formula. Where thyroid height, width, and depth of each lobe are measured and multiplied by a correction constituent [11]. Brunn et al. conducted a volumetric analysis of gland lobes by US in cadaver glands immersed in water [12]. Their results present a moderate correction constituent of 0.479 that will produce more correct assessment of the gland volume compared to the approved factor of $\pi / 6$ or 0.524 [12].

This study established with an aim to correlate the effects of body weight, height, and body mass index (BMI) on thyroid 
volume of healthy undergraduate Saudi males by using ultrasound.

\section{Materials and Methods}

\section{Participants}

After retaining an acceptance from the local ethics committee of College of Applied Medical Sciences, King Saud University, a total of 100 healthy undergraduate Saudi males were recruited between September 2016 and January 2018 in this prospective cohort study. All of the ultrasound measurements of the gland were performed by the same sonographer to avoid bias and any intra-observer errors. Participants with frontal neck swelling or clinical proof of gland disorder were excluded, since these may alter the volume of the gland.

\section{Technique}

Sonographic measurements of the gland were performed using a HI vision Avius ultrasound unit (Hitachi), equipped with a high frequency direct contact $10 \mathrm{MHz}$ linear array ultrasound probe. The Aquasonic 100 US gel was applied as a coupling material. Hard copies of thyroid sonographic images were obtained using US printer (Sony), $100 \mathrm{~V}$; $1.5 \mathrm{~A}$; and 50/60 Hz.

US examinations were conducted in a dorsal position with maximum neck extension. In each thyroid lobe a long and short axis US scan were used, as to obtain the length, width and depth in centimeters. Gland volume was fitted as a sum of lobe volumes $[13,14]$. The lobe volume was calculated using the rotation ellipsoid model formula $[15,16]$.

\section{Statistical analysis}

Data were initially sum up as mean \pm SD in a form of tables. Analysis was initiated using the Statistical Package for the Social Sciences (SPSS) transformation 20 for Windows (Microsoft). A P-value $<0.05$ was contemplating significant.

\section{Results}

Thyroid gland volume was estimated in 100 health undergraduate Saudi males. Participants' mean age was $21.8 \pm$ $1.3 \mathrm{y}$ and ranged from 18 to $22 \mathrm{y}$. The calculated mean of the gland volume was $7.5 \pm 2.8 \mathrm{ml}$. Right lobe volume was $3.9 \pm$ $1.6 \mathrm{ml}$ while that for left lobe was $3.6 \pm 1.2 \mathrm{ml}$ (Table 1). Among participants the greater volume detected for the gland was $13.5 \mathrm{ml}$, while the lesser volume was $2.4 \mathrm{ml}$.

As presented in Table 2, the mean height of participants was $172 \pm 7.9 \mathrm{~cm}$. Maximum participants' height was $200 \mathrm{~cm}$ and minimal height was $140 \mathrm{~cm}$. While in Table 3, the calculated mean weight of participants was $79.4 \pm 22.2 \mathrm{~kg}$. Also the maximum participants' weight was $147 \mathrm{~kg}$ and minimal weight was $46 \mathrm{~kg}$. The mean BMI was $26.8 \pm 7.4 \mathrm{~kg} / \mathrm{m}^{2}$.

Maximum participants' BMI was $49.7 \mathrm{~kg} / \mathrm{m}^{2}$ and minimal BMI was $16.2 \mathrm{~kg} / \mathrm{m}^{2}$. Also, the BMI of participants was ranged from $21.7 \pm 2.5 \mathrm{~kg} / \mathrm{m}^{2}$ to $138.5 \pm 12.02 \mathrm{~kg} / \mathrm{m}^{2}$ as shown in Table 4.

The results also demonstrate an extremely statistically significant relationship $(\mathrm{P}<0.0001)$ between the entire gland volume $(\mathrm{ml})$ and the participants' weight $(\mathrm{kg})(\mathrm{y}=-0.2 \mathrm{x}+80.8)$; $\left.\mathrm{R}^{2}=0.0004\right)$ where $(\mathrm{y})$ refers to body weight $(\mathrm{kg})$ and $(\mathrm{x})$ refers to the gland volume $(\mathrm{ml})$. Also, another significant correlation $(\mathrm{P}<0.0001)$ found between the mean thyroid volume $(\mathrm{ml})$ and participants' height $(\mathrm{cm})(\mathrm{y}=0.009 \mathrm{x}+172.2) ; \quad\left(\mathrm{R}^{2}=8 \mathrm{E}-06\right]$; where $(\mathrm{y})$ denotes to body height $(\mathrm{cm})$ and $(\mathrm{x})$ represents thyroid volume $(\mathrm{ml})$.

The two-tailed P-value was $<0.0001$ among participants BMI $\left(\mathrm{kg} / \mathrm{m}^{2}\right)$ and thyroid volume (ml) $(\mathrm{y}=-0.05 \quad \mathrm{x}+27.1)$; $\left(\mathrm{R}^{2}=0.0002\right)$; where $(\mathrm{y})$ denotes BMI $\left(\mathrm{kg} / \mathrm{m}^{2}\right)$ and $(\mathrm{x})$ presents thyroid volume $(\mathrm{ml})$, by conventional criteria, this difference is considered to be extremely statistically significant.

Table 1. Calculated thyroid gland volume $(\mathrm{ml})$.

\begin{tabular}{|c|c|c|c|}
\hline Variables & $\begin{array}{l}\text { Right lobe } \\
\text { volume (ml) }\end{array}$ & $\begin{array}{l}\text { Left lobe volume } \\
\text { (ml) }\end{array}$ & $\begin{array}{l}\text { Participants thyroid } \\
\text { volume }(\mathrm{ml})\end{array}$ \\
\hline $\mathrm{N}$ & 100 & 100 & 100 \\
\hline Mean & 3.9 & 3.6 & 7.5 \\
\hline$\pm \mathrm{SD}$ & \pm 1.6 & \pm 1.2 & \pm 2.8 \\
\hline
\end{tabular}

Table 2. Height (cm) of the participants.

\begin{tabular}{lll}
\hline $\begin{array}{l}\text { Range } \\
\text { participants' } \\
\text { (cm) }\end{array}$ & $\begin{array}{l}\text { of } \\
\text { height }\end{array}$ & $\begin{array}{l}\text { Frequency and percentage } \\
\text { of }\end{array}$
\end{tabular}

Table 3. Weight ( $\mathrm{kg}$ ) of participants.

\begin{tabular}{|c|c|c|c|}
\hline $\begin{array}{l}\text { Range } \\
\text { participants' } \\
\text { weight (kg) }\end{array}$ & of & $\begin{array}{lr}\text { Frequency } & \text { and } \\
\text { percentage } & \text { of } \\
\text { participants weight }(n ; \%)\end{array}$ & $\begin{array}{l}\text { Mean participants' weight } \\
(\mathrm{kg} \pm \mathrm{SD})\end{array}$ \\
\hline $46-66$ & & $36(36 \%)$ & $57.62 \pm 5.87$ \\
\hline $67-87$ & & $34(34 \%)$ & $76.54 \pm 5.79$ \\
\hline 88-108 & & $18(18 \%)$ & $96 \pm 4.82$ \\
\hline $109-129$ & & $10(10 \%)$ & $119.5 \pm 6.29$ \\
\hline $130-150$ & & $2(2 \%)$ & $138.5 \pm 12.02$ \\
\hline Total & & $100(100 \%)$ & $79.4 \pm 22.2$ \\
\hline
\end{tabular}


Table 4. BMI $\left(\mathrm{kg} / \mathrm{m}^{2}\right)$ of participants.

\begin{tabular}{|c|c|c|c|c|}
\hline $\begin{array}{l}\text { Range } \\
\text { participants' } \\
\left(\mathbf{k g} / \mathrm{m}^{2}\right)\end{array}$ & $\begin{array}{r}\text { of } \\
\text { BMI }\end{array}$ & $\begin{array}{l}\text { Frequency and } \\
\text { percentage of participants } \\
\text { BMI }(n ; \%)\end{array}$ & $\begin{array}{l}\text { Participant's } \\
\left(\mathrm{kg} / \mathrm{m}^{2} \pm \mathrm{SD}\right)\end{array}$ & BMI \\
\hline $16.2-26.2$ & & $59(59 \%)$ & $21.7 \pm 2.5$ & \\
\hline $26.3-36.3$ & & $27(27 \%)$ & $29.9 \pm 2.7$ & \\
\hline $36.4-46.4$ & & $13(13 \%)$ & $40.5 \pm 2.7$ & \\
\hline $46.5-56.5$ & & $1(1 \%)$ & $49.7 \pm 0.0$ & \\
\hline $130-150$ & & $2(2 \%)$ & $138.5 \pm 12.02$ & \\
\hline Total & & $100(100 \%)$ & $26.8 \pm 7.4$ & \\
\hline
\end{tabular}

\section{Discussion}

Accurate knowledge of thyroid gland dimension is necessary in the diagnosing of gland pathologies. Observation of the efficiency of the therapy in goiter is beneficial indicators for the prediction of hyperthyroidism. Although, in diffuse thyroid diseases the value of US may be limited to some extent [17]. Recently, the World Health Organization (WHO) has substituted the palpation by US measurement of gland volume as a diagnostic criterion for goiter. Thyroid dimension measurement is easy to gain, because it has a distinct echogenicity compare to neighboring structures [12]. Due to its cone-shaped morphemic, its lobe is supposed to mimic an ellipsoid, and its volume is calculated by multiplying height $\times$ width $\times$ depth $\times$ a correction factor. Also the automated transverse surface area method using the three-dimensional ultrasound (3D US) has been designed to rate thyroid volume $[18,19]$.

Our study revealed a mean gland volume of $7.5 \pm 2.4 \mathrm{ml}$. Such value is lesser than the value demonstrated by Hegedus et al. and Ivanac et al. and it's more than the volume presented by Kayastha et al. and Yousef et al. [3,5,20,21]. Due to the increasing in the usage of iodine supplementation in our region recently, this could be one of the reasons reducing iodine inadequacy and thus decreases goiter incidence. In addition, a notable inconsistency exists between the sizes of right and left thyroid in individual [22]. Where in our study, right lobe presents a volume of $3.9 \pm 1.6 \mathrm{ml}$ greater than that of left one, $3.6 \pm 1.2 \mathrm{ml}$ as presented in Table 1 .

In the current study an extremely statistically significant relation $(\mathrm{P}<0.0001)$ found between thyroid volume $(\mathrm{ml})$ and the participants' weight $\left.(\mathrm{kg})(\mathrm{y}=-0.2 \mathrm{x}+80.8) ; \mathrm{R}^{2}=0.0004\right]$. This finding is compatible with the results of Hegedus et al., Svensson et al., and Sari et al. [5,23,24]. Furthermore, Ivanac et al. correlated gland volume with participants height $(\mathrm{r}=0.37$; $\mathrm{P}=0.001$ ) [3]. Their findings supported our findings in this study, where a significant relationship $(\mathrm{P}<0.0001)$ was found between participants' thyroid volume $(\mathrm{ml})$ and their height (cm) $(\mathrm{y}=0.009 \mathrm{x}+172.2) ;\left(\mathrm{R}^{2}=8 \mathrm{E}-06\right)$.

The obtained results found that the two-tailed P-value is $<0.0001$ among participants BMI $\left(\mathrm{kg} / \mathrm{m}^{2}\right)$ and thyroid volume (ml) $(y=-0.05 x+27.1) ;\left(\mathrm{R}^{2}=0.0002\right)$, by conventional criteria, this difference is considered to be extremely statistically significant. Such finding was supported by Sari et al. in where they found a positive relation of thyroid volume with BMI $(\mathrm{r}=0.504, \mathrm{P}<0.001)$. In contrast to our findings, Kaloumenou et al. was detected a least correlation of thyroid volume with BMI $(\mathrm{r}=0.166, \mathrm{P}=0.023)[24,25]$.

Limitations of the current study, include the relatively small number of participants $(n=100)$, and the homogeneity of the sample (health undergraduate Saudi males). But the strength of this study comes from the fact that it is the first study carried in the kingdom of Saudi Arabia among healthy undergraduate Saudi males in the age of 18 to 22 years.

In conclusion, a local reference of thyroid volume among healthy undergraduate Saudi males was conducted. The volume of the right thyroid lobe found to be greater than the left one. In addition, the estimated thyroid volume was decreasing significantly as participants' weight and BMI increase. While in contrast, it increases significantly as height increases.

\section{Acknowledgments}

The authors extend their appreciation to the Deanship of Scientific Research in King Saud University for funding this work through undergraduate students' research program project No. (USRSP-15-48).

\section{References}

1. Rumack CM, Wilson SR, Charboneau JW, Levine D. Diagnostic ultrasound (4th edn.). Mosby 2010.

2. Kirsten D. The thyroid gland: physiology and pathophysiology. Neonatal Netw 2000; 19: 11-26.

3. Ivanac G, Rozman B, Skreb F, Brkljacic B, Pavic L. Ultrasonographic measurement of the thyroid volume. Coll Antropol 2004; 28: 287-291.

4. Ivarsson SA, Persson PH, Ericsson UB. Thyroid gland volume as measure by ultrasonography in healthy children and adolescents in a non-iodine deficient area. Acta Pediatr Scan 1989; 78: 633-634.

5. Hegedüs L, Perrild H, Poulsen LR, Andersen JR, Holm B, Schnohr P, Jensen G, Hansen JM. The determination of thyroid volume by ultrasound and its relationship to body weight, age, and sex in normal subjects. J Clin Endocrinol Metab 1983; 56: 260-263.

6. Daisuke U. Normal volume of the thyroid gland in children. J Clin Ultrasound 1990; 18: 455-462.

7. Ghervan C. Thyroid and parathyroid ultrasound. Med Ultrason 2011; 13: 80-84.

8. Gutekunst R, Smolarek H, Hasenpusch U, Stubbe P, Friedrich HJ, Wood WG, Scriba PC. Goitre epidemiology: thyroid volume, iodine excretion, thyroglobulin and thyrotropin in Germany and Sweden. Acta Endocrinol (Copenh) 1986; 112: 494-501. 
9. Van Herle AJ, Rich P, Ljung BE, Ashcraft MW, Solomon DH, Keeler EB. The thyroid nodule. Ann Intern Med 1982; 96: 221-232.

10. Klonoff DC, Greenspan FS. The thyroid nodule. Adv Intern Med 1982; 27: 101-103.

11. Brown MC, Spencer R. Thyroid gland volume estimated by use of ultrasound in addition to scintigraphy. Acta Radiol Oncol Radiat Phys Biol 1978; 17: 337-341.

12. Brunn J, Block U, Ruf G, Bos I, Kunze WP, Scriba PC. Volumetric analysis of thyroid lobes by real-time ultrasound. Dtsch Med Wochenschr 1981; 106: 1338-1340.

13. Kusixc Z, Dakovic N, Kaic-Rak A, Karner I, Lechpammer S, Mesaros-Simuncic E, Petrovic I, Roncevic S, Smoje J, Stanicic A, Valent I, Delange F. Current status of endemic goiter in Croatia: the results of a nationwide study. J Endocrinol Invest 1996; 19: 210-214.

14. Kusic Z, Lechpammer S. Successful struggle against iodine deficiency disorders (I.D.D.) in Croatia. Coll Antropol 1997; 21: 499-496.

15. Aghini-Lombardi F, Antonangeli L, Pinchera A, Leoli F, Rago T, Bartolomei AM, Vitti P. Effect of iodized salt on thyroid volume of children living in an area previously characterized by moderate iodine deficiency. J Clin Endocrinol Metab 1997; 82: 1136-1139.

16. Knudsen N, Bols B, Bulow I, Jorgensen T, Perrild H, Ovesen L, Laurberg P. Validation of ultrasonography of the thyroid gland for epidemiological purposes. Thyroid 1999; 9: 1069-1074.

17. DeGroot LJ, Jarsen PR, Hennemann G. The thyroid and its diseases, 6th ED Churchill Livingstone Pull 1996.

18. Schlögl S, Werner E, Lassmann M, Terekhova J, Muffert S, Seybold S, Reiners C. The use of three-dimensional ultrasound for thyroid volumetry. Thyroid 2001; 11: 569-574.

19. Shabana W, Peeters E, Verbeek P, Osteaux MM. Reducing inter-observer variation in thyroid volume calculation using a new formula and technique. Eur J Ultrasound 2003; 16 : 207-210.

20. Kayastha P, Paudel S, Shrestha DM, Ghimire RJ, Pradhan S. Study of thyroid volume by ultrasonography in clinically euthyroid patients. J Inst Med 2010; 32: 36-43.

21. Yousef M, Sulieman A, Ahmed B, Abdella A, Eltom K. Local reference ranges of thyroid volume in Sudanese normal subjects using ultrasound. J Thyroid Res 2011; 2011: 935141 .

22. Perry R, Hollman A, Wood A, Donaldson M. Ultrasound of the thyroid gland in the newborn: normative data. Arch Dis Child Fetal Neonatal Ed 2002; 87: 209-211.

23. Svensson J, Nilsson PE, Olsson C, Nilsson JA, Lindberg B, Ivarsson SA. Interpretation of normative thyroid volumes in children and adolescents: is there a need for a multivariate model? Thyroid 2004; 14: 536-543.

24. Sari R, Balci MK, Altunbas H, Karayalcin U. The effect of body weight and weight loss on thyroid volume and function in obese women. Clin Endocrinol (Oxf) 2003; 59: 258-262.

25. Kaloumenou I, Alevizaki M, Ladopoulos C, Antoniou A, Duntas LH, Mastorakos G, Chiotis D, Mengreli C, Livadas $\mathrm{S}$, Xekouki P, Dacou-Voutetakis C. Thyroid volume and echostructure in schoolchildren living in an iodine-replete area: relation to age, pubertal stage, and body mass index. Thyroid 2007; 17: 875-881.

\section{*Correspondence to}

Fahad A. Alsaqer

Department of Radiological Sciences

College of Applied Medical Sciences

King Saud University

Saudi Arabia 